\title{
DISCUSSION
}

\section{Mohr-Coulomb failure envelopes of lime-treated soils}

\author{
N. C. CONSOLI*, L. DA SILVA LOPES JR ${ }^{\dagger}$, B. S. CONSOLI* L. FESTUGATO*, M. DI SANTE*, \\ E. FRATALOCCHI ${ }^{*}$ and F. MAZZIERI ${ }^{\star}$
}

\section{Contribution by M. Di Sante, E. Fratalocchi and F. Mazzieri} The paper by Consoli et al. (2014) analyses the influence of lime content and porosity on the Mohr-Coulomb failure envelopes of lime-treated soils. A methodology for establishing the failure envelopes based on unconfined compression and splitting tensile tests is proposed. The advantage offered by this methodology is that the values of shear strength parameters can be predicted by basic tests without the necessity to carry out more complex triaxial testing.

The proposed methodology has been successfully tested for a given soil, a specific hydrated lime and for long-term (90 and 360 days) curing conditions.

The discussers would like to comment on some aspects dealt with in the paper in light of their experience with lime-treated soils (Di Sante et al., 2014, 2015) and to make their contribution to the research by presenting the results of the application of the methodology proposed by the authors to a soil with different characteristics, treated with quicklime instead of hydrated lime and tested at 7 days of curing.

The studied soil is a clayey soil of low plasticity (CL), according to the Unified Soil Classification System (USCS, ASTM D2487-93 (ASTM, 1993)). Its characteristics are summarised in Table 4 . The studied soil fully matches the suitable grain size distribution requirements for lime treatment. The lime used in this study is a fine calcic quicklime, classified as CL80-Q (UNI EN 459-1 (UNI, 2002) - calcium oxide $(\mathrm{CaO})>87 \%$, magnesium oxide $(\mathrm{MgO})<5 \%$, completely passing through the ASTM 200 sieve $(75 \mu \mathrm{m}$ sieve opening). The unit weight of quicklime solids is equal to $33 \cdot 7$ $\mathrm{kN} / \mathrm{m}^{3}$.

The preparation procedure is different with respect to the study by Consoli et al. because the lime is added to the soil in the wet state. To the knowledge of the discussion contributors, this procedure better represents what happens at construction sites (Fratalocchi et al., 2009), although the mixing stage needs to be more accurate to guarantee the same homogeneous distribution of lime achieved with dry mixing.

The compacted samples were moulded by dynamic compaction in three or five layers according to ASTM D698-12 (ASTM, 2012a) for the standard Proctor energy and to ASTM D1557-12 (ASTM 2012b) for the modified Proctor energy, respectively. Samples compacted with reduced effort (three layers, 15 blows per layer, with the same rammer as the standard Proctor) were also tested. The lime percentage ranged from 2 to $4 \%$ by dry weight of soil. These amounts of lime are lower than those tested by the authors, owing to the higher reactivity of quicklime. Distinct compaction curves were obtained for a given effort and lime content. Different

\footnotetext{
* Department of Civil Engineering, Federal University of Rio Grande do Sul, Porto Alegre, RS, Brazil.

$\dagger$ Formerly Department of Civil Engineering, Federal University of Rio Grande do Sul, Porto Alegre, RS, Brazil.

t Department of Materials, Environmental Sciences and Urban Planning, Faculty of Engineering, Technical University of Marche, Ancona, Italy.
}

compaction efforts were applied, obtaining samples with dry unit weight ranging from 16 to $18 \mathrm{kN} / \mathrm{m}^{3}$. The samples prepared for strength tests were compacted at the optimum water content of each compaction curve.

Unconfined compression tests and splitting tensile tests were carried out at 7 days of curing. Fig. 11 presents the unconfined compressive strength (UCS) as a function of the adjusted porosity/lime ratio $\eta /\left(L_{\mathrm{iv}}\right)^{0 \cdot 12}$ defined by Consoli et al. (2011). The experimental data are well fitted by a power law (equation (11)), confirming the findings by Consoli et al. (2011). The range of the obtained UCS values is similar to that described in the paper, although the curing time is significantly lower. This could be due to the high clay fraction of the soil and to the highly reactive nature of the lime used. Moreover, quicklime hydration causes a rise in temperature that accelerates the pozzolanic reactions, known as being very sensitive to temperature (Al-Mukhtar et al., 2010).

$$
\mathrm{UCS}(\mathrm{kPa})=2 \times 10^{8}\left[\frac{\eta}{\left(L_{\mathrm{iv}}\right)^{0.12}}\right]^{-3 \cdot 591}
$$

The splitting tensile strengths were divided by the UCS at the same condition of moulding and curing, yielding the scalar $\xi=0 \cdot 1$.

In order to verify the predictions of the proposed methodology, the obtained results were compared with drained triaxial compression tests carried out on specimens prepared with 3 and 4\% (by weight) of lime, compacted with standard effort at optimum water content, tested after 7 days of curing.

Table 4. Studied soil characteristics

\begin{tabular}{l|l}
\hline Sand $(<2 \mathrm{~mm}): \%$ & 3 \\
Fine $(<0 \cdot 075 \mathrm{~mm}): \%$ & 97 \\
Clay $(<0 \cdot 002 \mathrm{~mm}): \%$ & 39 \\
Specific gravity & $2 \cdot 77$ \\
Liquid limit: $\%$ & 40 \\
Plasticity limit: $\%$ & 20 \\
USCS class & CL \\
\hline
\end{tabular}

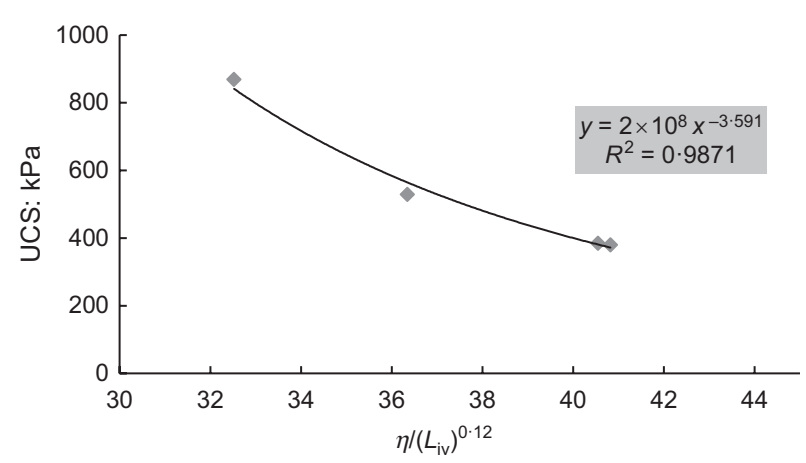

Fig. 11. Variation of UCS with adjusted porosity/lime ratio $\eta /\left(L_{\mathrm{iv}}\right)^{0 \cdot 12}$ at 7 days of curing 
The tests were carried out according to UNI CEN ISO/TS 17892-9 (UNI CEN, 2004).

Figure 12 and Fig. 13 show the Mohr semi-circles and the failure envelopes for the $3 \%$ and $4 \%$ lime content,

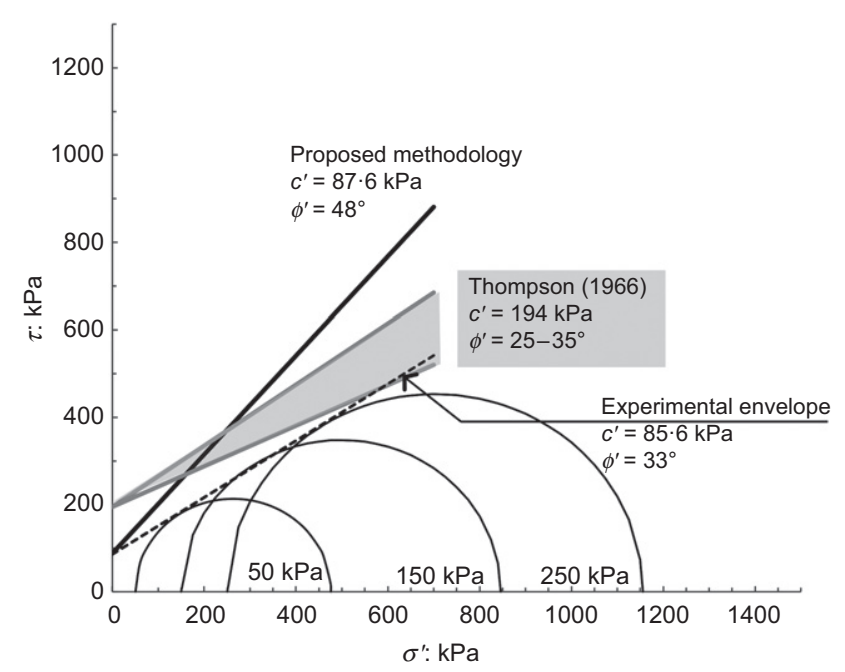

Fig. 12. Mohr-Coulomb failure envelopes for $3 \%$ of quicklime content

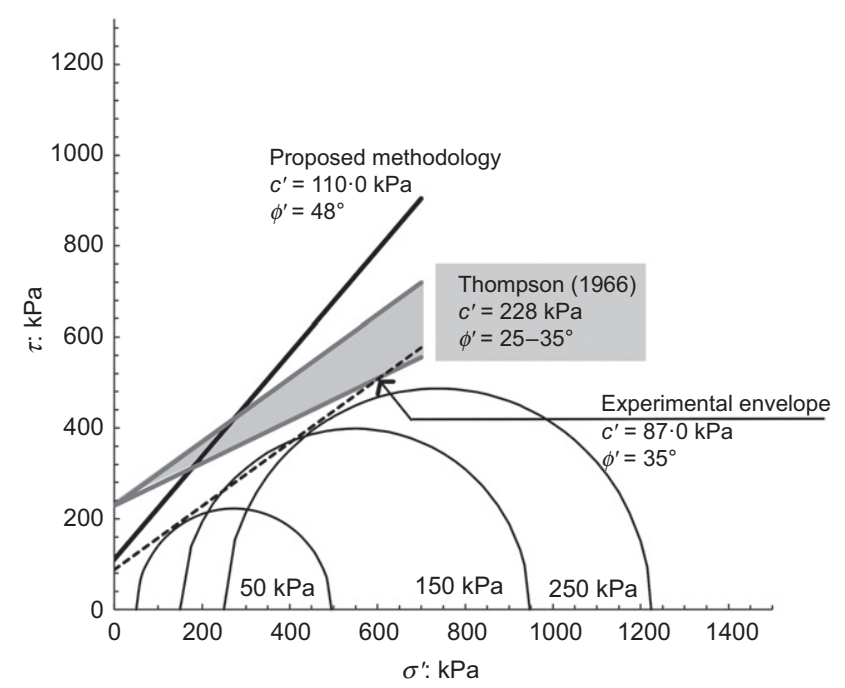

Fig. 13. Mohr-Coulomb failure envelopes for $4 \%$ of quicklime content respectively. In the discussion contributors' case, for the tested mixtures, the proposed method reasonably predicts the cohesion values but overestimates the shear angle. The relatively good accordance between experimental and predicted cohesion values is justified because the UCS and the tensile strength are deeply influenced by the pozzolanic reactions, which also increase the shear resistance values producing high cohesion values. Therefore the methodology based on the relationship between the cohesion and the strengths gives a good estimate.

The experimental values of the shear resistance angle obtained by the triaxial tests in the present application lay close to the upper bound of the range $\left(25-35^{\circ}\right)$ originally proposed by Thompson (1966) and later reported by Mitchell (1981). Therefore a possible working methodology could be to combine the findings of Thompson with the proposed methodology. This could be done by adopting the cohesion values predicted by the proposed methodology and assuming $35^{\circ}$ as the upper bound for the predicted shear angle.

Given the differences in soil, lime, curing time and preparation procedure herein reported, it is the discussion contribtors' opinion that this note helps in evaluating the methodology proposed in the paper by presenting an application to a different case. Further studies will be useful to corroborate the findings.

\begin{abstract}
Authors' reply
The authors wish to thank the discussers for their contribution. It is interesting to see the results of this research developed in Brazil being applied overseas. The discussion contributors have applied the methodology proposed by the authors to a soil with different characteristics (clayey soil of low plasticity (CL)), treated with 3 and $4 \%$ of quicklime instead of hydrated lime and tested at 7 days of curing. In the discussion contributors' case study, for the tested mixtures, the proposed methodology reasonably predicts the cohesion intercept values but overestimates the friction angle. Based on such results, the discussion contributors are suggesting the use of a possible working methodology combining the findings of Thompson (1966), with the proposed methodology. The discussion contributors suggest adopting the cohesion values predicted by the proposed methodology and assuming $35^{\circ}$ as the predicted friction angle.
\end{abstract}

The authors believe that, before going to such empiricism, which needs further testing with other clayey soils and only could be used for clayey soils treated with lime, further testing should be carried out using the methodology proposed by the

Table 5. Proposed methodology against Mohr-Coulomb failure envelopes for different studies

\begin{tabular}{|c|c|c|c|c|c|c|c|c|}
\hline \multirow[t]{2}{*}{ Soil matrix } & \multirow[t]{2}{*}{ Binder } & \multirow{2}{*}{$\begin{array}{l}\text { Curing } \\
\text { time: } \\
\text { days }\end{array}$} & \multirow[t]{2}{*}{$\xi$} & \multicolumn{2}{|c|}{$\begin{array}{l}\text { Proposed } \\
\text { methodology }\end{array}$} & \multicolumn{2}{|c|}{$\begin{array}{l}\text { Mohr-Coulomb } \\
\text { failure envelopes }\end{array}$} & \multirow[t]{2}{*}{ Reference } \\
\hline & & & & $\phi^{\prime}: \operatorname{deg}$ & $c^{\prime}: \mathrm{kPa}$ & $\phi^{\prime}: \operatorname{deg}$ & $c^{\prime}: \mathrm{kPa}$ & \\
\hline $\begin{array}{l}\text { Clayey sand-- } \\
\text { fly ash }\end{array}$ & $\begin{array}{l}\text { Hydrated lime } \\
\qquad\left[\eta /\left(L_{\mathrm{iv}}\right)^{0 \cdot 12}\right]=35\end{array}$ & 28 & $0 \cdot 135$ & $39 \cdot 1$ & $289 \cdot 0$ & $33 \cdot 2$ & $404 \cdot 3$ & Consoli et al. (2015) \\
\hline $\begin{array}{l}\text { Clayey sand-- } \\
\text { fly ash }\end{array}$ & $\begin{array}{l}\text { Hydrated lime } \\
\qquad\left[\eta /\left(L_{\mathrm{iv}}\right)^{0 \cdot 12}\right]=35\end{array}$ & 90 & $0 \cdot 135$ & $39 \cdot 1$ & $720 \cdot 0$ & $44 \cdot 6$ & $668 \cdot 3$ & Consoli et al. (2015) \\
\hline Silty sand & Portland cement $(C=1 \%)$ & 7 & $0 \cdot 135$ & $39 \cdot 1$ & $73 \cdot 2$ & $41 \cdot 1$ & $56 \cdot 7$ & Consoli (2014) \\
\hline Silty sand & Portland cement $(C=3 \%)$ & 7 & $0 \cdot 135$ & $39 \cdot 1$ & $176 \cdot 9$ & $44 \cdot 0$ & $137 \cdot 6$ & Consoli (2014) \\
\hline Silty sand & Portland cement $(C=5 \%)$ & 7 & $0 \cdot 135$ & $39 \cdot 1$ & $280 \cdot 3$ & $39 \cdot 0$ & $276 \cdot 7$ & Consoli (2014) \\
\hline Osorio sand & Portland cement $\eta / C_{\mathrm{iv}}=10$ & 7 & $0 \cdot 150$ & $34 \cdot 9$ & $369 \cdot 0$ & $38 \cdot 3$ & $346 \cdot 0$ & $\begin{array}{l}\text { Consoli et al. }(2010 \text {, } \\
2012 \mathrm{a}, 2012 \mathrm{~b})\end{array}$ \\
\hline Osorio sand & Portland cement $\eta / C_{\mathrm{iv}}=17$ & 7 & $0 \cdot 150$ & $34 \cdot 9$ & $185 \cdot 0$ & $33 \cdot 4$ & $190 \cdot 0$ & $\begin{array}{c}\text { Consoli et al. (2010, } \\
\text { 2012a, 2012b) }\end{array}$ \\
\hline Osorio sand & Portland cement $\eta / C_{\mathrm{iv}}=30$ & 7 & $0 \cdot 150$ & $34 \cdot 9$ & $88 \cdot 5$ & $27 \cdot 3$ & $102 \cdot 7$ & $\begin{array}{c}\text { Consoli et al. (2010, } \\
\text { 2012a, 2012b) }\end{array}$ \\
\hline
\end{tabular}


authors, which in principle does not have any restrictions about binders and soils used. To do so, the authors went to existing literature and checked their methodology to the same soil treated with fly ash and hydrated lime, as well as a silty sand treated with standard Portland cement. Following this, the authors checked the efficiency of the methodology with uniform sand treated with early strength Portland cement. The results of different studies were gathered and their outcomes are presented in Table 5.

As a conclusion, the methodology proposed by the authors has presented a sound estimation of the failure envelope parameters for distinct binders and soils. A few poor representations of the failure envelope obtained considering the proposed methodology were observed for weak cementation levels at high confining pressures. In such cases the Mohr semi-circles are far below the failure envelope obtained based on the methodology developed herein - using unconfined compression and splitting tensile tests, which can be explained by possible cementitious bonding breakage (yielding) occurring during application of confining stresses, as explained by Consoli et al. (2000) and Dalla Rosa et al. (2008). High porosities combined with low degrees of cementation and high stress levels lead the failure envelope to be curved rather than a straight line.

\section{REFERENCES}

Al-Mukhtar, M., Lasledj, A. \& Alcover, JF (2010). Behaviour and mineralogy changes in lime treated expansive soil at $50^{\circ} \mathrm{C}$. Appl. Clay Sci. 50, No. 2, 199-203, http://dx.doi.10.1016/j.clay.2010. 07.022 .

ASTM (1993). D2487: Standard practice for classification of soils for engineering purposes (Unified Soil Classification System). West Conshohocken, PA, USA: ASTM International.

ASTM (2012a). D698: Standard test methods for laboratory compaction characteristics of soil using standard effort. West Conshohocken, PA, USA: ASTM International.

ASTM (2012b). D1557: Standard test methods for laboratory compaction characteristics of soil using modified effort. West Conshohocken, PA, USA: ASTM International.

Consoli, N. C. (2014). A method proposed for the assessment of failure envelopes of cemented sandy soils. Engng Geol. 169, February, 61-68, http://dx.doi.org/10.1016/j.enggeo.2013. 11.016.

Consoli, N. C., Rotta, G. V. \& Prietto, P. D. M. (2000). Influence of curing under stress on triaxial response of cemented soils. Géotechnique 50, No. 1, 99-105, http://dx.doi.org/10. 1680/geot.2000.50.1.99.

Consoli, N. C., Cruz, R. C., Floss, M. F. \& Festugato, L. (2010). Parameters controlling tensile and compressive strength of artificially cemented sand. J. Geotech. Geoenviron. Engng 136, No. 5, 759-763, http://dx.doi.org/10.1061/(ASCE)GT.19435606.0000278 .
Consoli, N. C., Lopes, L. S. Jr, Prietto, P. D. M., Festugato, L. \& Cruz, R. C. (2011). Variables controlling stiffness and strength of lime-stabilized soils. J. Geotech. Geoenviron. Engng ASCE 137, No. 6, 628-632, http://dx.doi.org/10.1061/(ASCE)GT. 1943-5606.0000470.

Consoli, N. C., Viana da Fonseca, A., Silva, S. R., Cruz, R. C. \& Fonini, A. (2012a). Parameters controlling stiffness and strength of artificially cemented soils. Géotechnique 62, No. 2, 177-183, http://dx.doi.org/10.1680/geot.8.P.084.

Consoli, N. C., Cruz, R. C., Viana da Fonseca, A. \& Coop, M. R. (2012b). Influence of cement-voids ratio on stress-dilatancy behavior of artificially cemented sand. J. Geotech. Geoenviron. Engng 138, No. 1, 100-109, http://dx.doi.org/10.1061/(ASCE) GT.1943-5606.0000565.

Consoli, N. C., Da Silva Lopes, L. Jr, Consoli, B. S. \& Festugato, L. (2014). Mohr-Coulomb failure envelopes of lime-treated soils. Géotechnique 64, No. 2, 165-170, http://dx.doi.org/ 10.1680/geot.12.P.168.

Consoli, N. C., Festugato, L., Consoli, B. S. \& Lopes, L. S. Jr (2015). Assessing failure envelopes of soil-fly ash-lime blends. J. Mater. Civ. Engng, 04014174-1-04014174-8, http://dx.doi. org/10.1061/(ASCE)MT.1943-5533.0001134.

Dalla Rosa, F., Consoli, N. C. \& Baudet, B. A. (2008). An experimental investigation of the behavior of artificially cemented soil cured under stress. Géotechnique 58, No. 8, 675-679, http://dx.doi.org/10.1680/geot.2008.58.8.675.

Di Sante, M., Fratalocchi, E., Mazzieri, F. \& Pasqualini, E. (2014). Time of reaction in a lime treated clayey soil and influence of curing conditions on its microstructure and behavior. Appl. Clay Sci. 99, 100-109, http://dx.doi.10.1016/j.clay. 2014.06.018.

Di Sante, M., Fratalocchi, E., Mazzieri, F. \& Brianzoni, V. (2015). Influence of delayed compaction on the compressibility and hydraulic conductivity of soil-lime mixtures. Engng Geol. 185, 131-138, http://dx.doi.10.1016/j.enggeo. 2014.12.005.

Fratalocchi, E., Bellezza, I., Di Sante, M. \& Pasqualini, E. (2009). Mix-design, construction and controls of lime stabilized embankments. In Proceedings of the 17th international conference on soil mechanics and geotechnical engineering (eds M. Hamza, M. Shahien and Y. El-Mossallamy), vol. 3, pp. 2248-2251. Rotterdam, the Netherlands: IOS Press.

Mitchell, J. K. (1981). Soil improvement - state-of-the-art report. Proceedings of the 10th international conference on soil mechanics and foundation engineering, vol. 4, 509-565. Stockholm, Sweden: International Society of Soil Mechanics and Foundation Engineering.

Thompson, M. R. (1966). Shear strength and elastic properties of lime-soil mixtures. Highway Res. Record No. 139, 1-14.

UNI CEN (2004). ISO/TS 17892-9: Geotechnical investigation and testing - Laboratory testing of soil - Part 9: Consolidated triaxial compression tests on water saturated soil. Milan, Italy: Ente nazionale Italiano di Unificazione (in Italian).

UNI (2002). EN 459-1: Calci da costruzione. Definizioni, specifiche e criteri di conformità. Milan, Italy: Ente nazionale Italiano di Unificazione (in Italian). 